\title{
Growth of the Aquatic Plant Southern Naiad in Varying Percentages of Sand and Controlled- release Fertilizer
}

\author{
Heather Hasandras ${ }^{1}$, Kimberly A. Moore ${ }^{2,4}$, and Lyn A. Gettys ${ }^{3}$
}

ADDITIONAL INDEX WORDs. native aquatic plant, invasive aquatic plant, production, Najas guadalupensis

SUMMARY. Native aquatic plants are important to maintaining a balanced ecosystem, but they often are displaced by exotic invasive plant species. The research on the control and growth of the invasive aquatic species hydrilla (Hydrilla verticillata) using sand substrates and controlled-release fertilizers (CRF) provides a potential production technique for other aquatic plants. We questioned if we could use hydrilla production techniques to grow southern naiad (Najas guadalupensis), a Florida-native aquatic plant that is often mistaken for hydrilla. We grew southern naiad cuttings in containers filled with 100:0, 75:25, 50:50, 25:75, or 0:100 coarse builder's sand and sphagnum moss (by volume). Before planting, containers were fertilized with $0,1,2$, or $4 \mathrm{~g} \cdot \mathrm{kg}^{-1} \mathrm{CRF}(15 \mathrm{~N}-4 \mathrm{P}-10 \mathrm{~K})$. Containers were submerged in large storage tubs filled with rainwater and grown for 8 weeks. Southern naiad shoot dry weight was greater in the $100 \%$ sand substrate than that in the $0 \%$ sand substrate. Substrate electrical conductivity (EC) levels were greater in the $\mathbf{0 \%}$ sand with no difference among the other substrates. Shoot and root dry weight of plants fertilized with $1-2 \mathrm{~g} \cdot \mathrm{kg}^{-1}$ CRF were greater than 0 or $4 \mathrm{~g} \cdot \mathrm{kg}^{-1} \mathrm{CRF}$.

Substrate EC also increased as fertilizer rate increased, with the highest EC observed at $4 \mathrm{~g} \cdot \mathrm{kg}^{-1}$ CRF. Based on our results, we would suggest growing southern naiad in substrates with $100 \%$ sand and fertilized with $1-2 \mathrm{~g} \cdot \mathrm{kg}^{-1} \mathrm{CRF}$.

$\mathrm{C}$ onservation of aquatic plant areas is crucial to promote a balanced ecosystem of food and habitats for fish and birds. Natural interactions in aquatic communities are supported by native aquatic plants that help improve water quality by removing nutrients, controlling erosion, and contributing to the asthetic beauty of water bodies (Madsen et al., 2008; Main et al., 2006).

However, diversity of native aquatic plants is reduced by the introduction of exotic (nonnative) invasive aquatic plants that choke waterways, change nutrient cycles, and reduce recreational use of water bodies (Dibble et al., 1996; Godfrey and Wooten, 1981; Office of Technology Assessment, 1993). The removal of invasive aquatic plants is necessary to restore balance in native aquatic systems.

University of Florida, IFAS, Fort Lauderdale Research and Education Center, 3205 College Avenue, Davie, FL 33314

${ }^{1}$ Graduate Student.

${ }^{2}$ Professor

${ }^{3}$ Assistant Professor.

${ }^{4}$ Corresponding author. E-mail: klock@ufl.edu.

https://doi.org/10.21273/HORTTECH03987-18
Southern naiad may prove to be a good candidate to reestablish some aquatic plant communities in natural areas previously colonized by invasive plants (Smart et al., 1996). Because it is superficially similar in form/habit and grows in similar areas, southern naiad is a Florida-native plant that is often mistaken for the invasive weed hydrilla (University of Florida, 2015).

Hydrilla control and growth in different substrates and at fertilizer rates has been researched (Mony et al., 2007; Sutton, 1990), whereas studies on the growth of southern naiad have focused on its roles in fish communities rather than on its growth. Because of their similarity, we questioned if we could use similar production protocols developed with hydrilla to grow southern naiad to increase its production and expand its use in natural aquatic ecosystem restoration. The objective of this study was to determine which substrate and controlled-release fertilizer rate would result in the best southern naiad growth to establish a production protocol for southern naiad using standard greenhouse supplies.

\section{Materials and methods}

Cuttings of southern naiad $(\approx 4-6$ inches long) were collected from cultures of southern naiad maintained in the aquatic tanks located at the University of Florida, Fort Lauderdale Research and Education Center, Davie, FL (FLREC). Plants were originally collected from Lake Okeechobee, FL. Containers without drainage holes with dimensions 10 inches tall by 4 inches diameter were filled to a depth of 8 inches with $100: 0,75: 25,50: 50,25: 75$, or 0:100 (by volume) coarse builder's sand (Muti-Purpose Sand; Sakrete, Charlotte, NC): sphagnum moss (Premier Horticulture, Quakertown, PA). A $15 \mathrm{~N}-4 \mathrm{P}-10 \mathrm{~K}$ controlledrelease fertilizer (Osmocote 15-912; ICL Specialty Fertilizers, Dublin, $\mathrm{OH})$ was distributed evenly (layered) onto the substrates at $0,1,2$, or 4 $\mathrm{g} \cdot \mathrm{kg}^{-1}$. We filled each container to within 1 inch of the rim of the container and then planted 10 cuttings into each container. The CRF was layered $\mathrm{l}$ inch under the top of the substrate.

We use a randomized block design with 12 plastic 18 -gal rectangular tubs (large storage tubs) filled with rainwater from surface ponds at the research center to create a submerged growing environment [three blocks (large storage tubs) per fertilizer rate

\begin{tabular}{llll}
\hline $\begin{array}{l}\text { Units } \\
\text { To convert U.S. to SI, } \\
\text { multiply by }\end{array}$ & U.S. unit & SI unit & $\begin{array}{l}\text { To convert SI to U.S., } \\
\text { multiply by }\end{array}$ \\
\hline 10 & $\%$ & $\mathrm{~g} \cdot \mathrm{L}^{-1}$ & 0.1 \\
29.5735 & $\mathrm{fl} \mathrm{oz}$ & $\mathrm{mL}$ & 0.0338 \\
3.7854 & gal & $\mathrm{L}$ & 0.2642 \\
2.54 & inch $(\mathrm{es})$ & $\mathrm{cm}$ & 0.3937 \\
1 & $\mathrm{mmho} / \mathrm{cm}$ & $\mathrm{dS} \cdot \mathrm{m}^{-1}$ & 1 \\
28.3495 & $\mathrm{oz}$ & $\mathrm{g}$ & 0.0353 \\
28,350 & $\mathrm{oz}$ & $\mathrm{mg}$ & $3.5274 \times 10^{-5}$ \\
0.001 & $\mathrm{ppm}$ & $\mathrm{g} \cdot \mathrm{kg}^{-1}$ & 1,000 \\
0.001 & $\mathrm{ppm}$ & $\mathrm{mg} \cdot \mathrm{g}^{-1}$ & 1,000 \\
10.7639 & $\mathrm{~W} / \mathrm{ft}^{2}$ & $\mathrm{~W} \cdot \mathrm{m}^{-2}$ & 0.0929 \\
$\left({ }^{\circ} \mathrm{F}-32\right) \div 1.8$ & $\mathrm{o} F$ & ${ }^{\circ} \mathrm{C}$ & $\left({ }^{\circ} \mathrm{C} \times 1.8\right)+32$
\end{tabular}


$0,1,2$, and $\left.4 \mathrm{~g} \cdot \mathrm{kg}^{-1} \mathrm{CRF}\right]$. Each large storage tub contained one container of each substrate treatment for that fertilizer rate. The experiment ran for
8 weeks in Aug. to Sept. 2014 (Expt. 1) and was repeated in June to July 2015 (Expt. 2). Large storage tubs were arranged in an open-sided greenhouse at FLREC and exposed to ambient conditions [average conditions for Expts. 1 and 2 were: average air temperatures 25 to
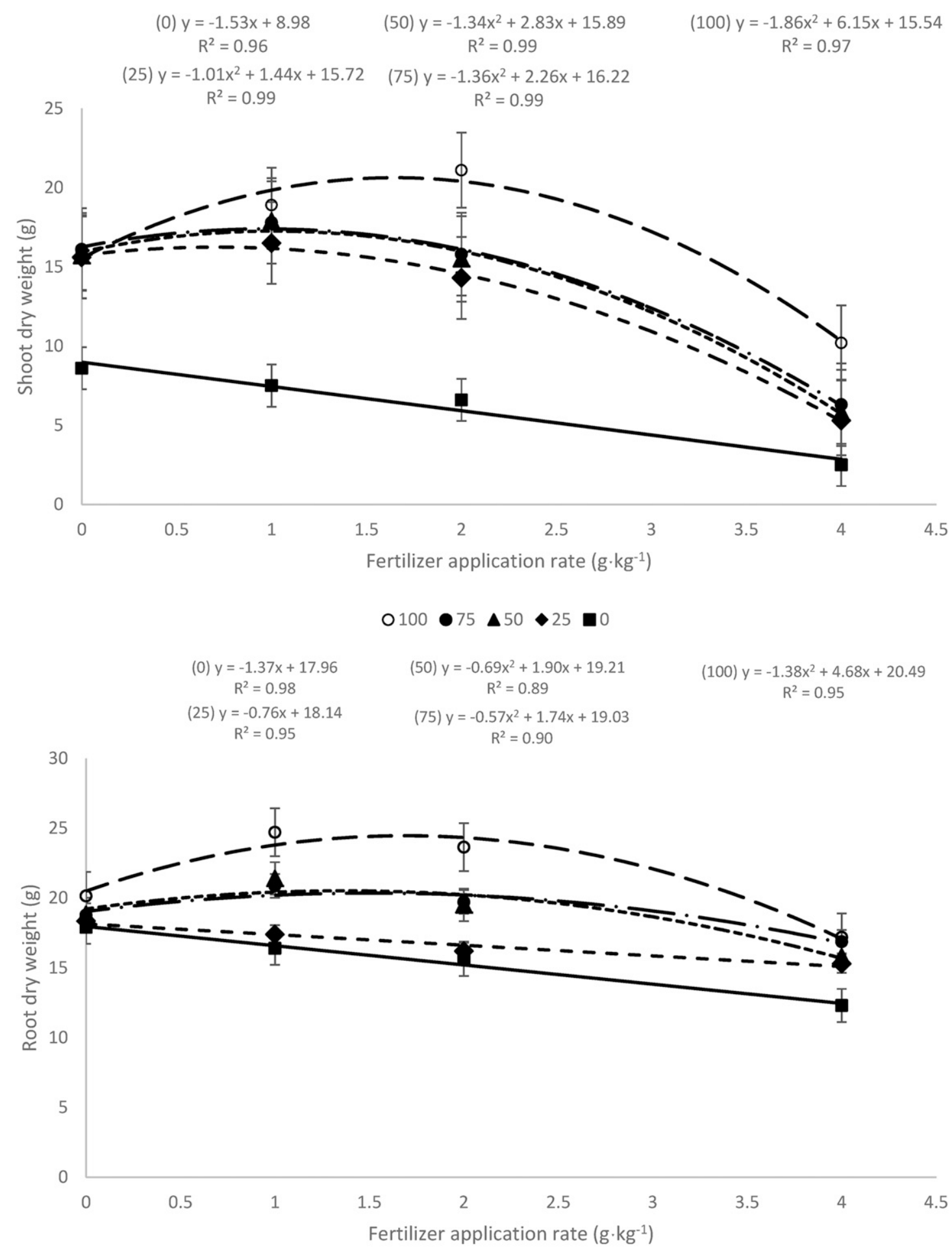

0100

- $75 \Delta 50 \bullet 25 \square 0$

Fig. 1. Mean southern naiad shoot and root dry weight of plants fertilized with $0,1,2$, or $4 \mathrm{~g} \cdot \mathrm{kg}^{-1}$ controlled-release fertilizer and grown in 100:0, 75:25, 50:50, 25:75, or 0:100 sand:peat substrate (by volume). Data were pooled from Expts. 1 and 2 conducted in Aug. to Sept. 2014 and June to July 2015, respectively, at the University of Florida, Fort Lauderdale Research and Education Center (Davie, FL). The numbers 100,75, 50, 25, and 0 in the figure refer to the percent sand in the substrate. Bars represent SE; $1 \mathrm{~g} \cdot \mathrm{kg}^{-1}=1000 \mathrm{ppm}, 1 \mathrm{~g}=0.0353 \mathrm{oz}$. 
$27{ }^{\circ} \mathrm{C}, 79 \%$ to $80 \%$ relative humidity, and average solar radiation 203-226 $\mathrm{W} \cdot \mathrm{m}^{-2}$ ]. In Expt. 1, we topped the containers with $50 \%, 25 \%$, and $0 \%$ sand substrate with small rocks to prevent the containers from floating once submerged in the large storage tubs. We planted the cuttings between the pebbles. In Expt. 2, we covered the containers with $50 \%$, $25 \%$, and $0 \%$ sand with weed cloth and we inserted cuttings into holes made in the weed cloth before top dressing the substrate with small rocks to prevent flotation.

For both experiments, after 8 weeks of growth, we harvested shoots and roots from each container in the large storage tubs. To determine shoot and root dry weight, we washed plant tissue clean of debris using a screen for straining and placed shoots and roots in a forced air oven set at $90{ }^{\circ} \mathrm{C}$ until a constant weight was achieved.

In Expt. 2, we collected final water samples from each large storage tub to determine $\mathrm{pH}$, EC, nitratenitrogen $\left(\mathrm{NO}_{3}-\mathrm{N}\right)$, phosphatephosphorus $\left(\mathrm{PO}_{3}-\mathrm{P}\right)$, and potassium (K). We also collected substrate samples from all containers in each large storage tub to determine final $\mathrm{pH}$ and EC using the 1:2 extraction method (Lang, 1996). Water and substrate $\mathrm{pH}$ and EC were determined using a combo $\mathrm{pH}$ and $\mathrm{EC}$ waterproof meter (H198129; Hanna Instruments, Woonsocket, RI). Water $\mathrm{NO}_{3}-\mathrm{N}$ and $\mathrm{K}$ were determined using a combination ion-selective electrode (Accumet XL250; Thermo Fisher Scientific, Waltham, MA). We measured phosphate-phosphorus $\left(\mathrm{PO}_{4}-\mathrm{P}\right)$ levels by using the ascorbic acid method using a spectrophotometer (Spectronic 20D+; Thermo Fisher Scientific) measuring absorbance at $440 \mathrm{~nm}$.

Shoots from Expt. 2 were ground using a Wiley Mill (Thomas Scientific, Swedesboro, NJ) to pass through a 40 -mesh screen to ensure homogeneity. The shoots $(0.5 \mathrm{~g})$ were placed into a $30-\mathrm{mL}$ porcelain crucible and dry ashed to determine total phosphorus $(\mathrm{P})$ and $\mathrm{K}$ using a muffle furnace (Thermolyne F48010-33; Thermo Fisher Scientific) capable of $500{ }^{\circ} \mathrm{C}$. The ash was dissolved with $10 \mathrm{~mL} 1.0 \mathrm{~N}$ hydrochloric acid $(\mathrm{HCl})$ solution. The contents of the crucible for each sample were transferred into a $50-\mathrm{mL}$ volumetric flask, diluted with deionized water to volume, capped, and inverted three times. Samples were filtered through a filter paper (Whatman ${ }^{\mathrm{TM}}$ no. 1; GE Healthcare Company, Little Chalfont, UK) into $50-\mathrm{mL}$ plastic bottles. This digestate was used for nutrient analysis of $\mathrm{P}$ and $\mathrm{K}$. Phosphorus was determined by using the ammonium molybdate colorimetric method using the spectrophotometer. Analysis for $\mathrm{K}$ was performed by using atomic absorption spectrometry (Analyst 400; Perkin Elmer, Waltham, MA). Extractable $\mathrm{NO}_{3}-\mathrm{N}$ was determined by mixing $200 \mathrm{mg}$ of ground tissue with acetic acid extracting solution and analyzing the filtrate with an autoanalyzer (Seal Autoanalyzer 3; Seal Analytical, Mequon, WI) (Miller, 1998).

Dry weights, water analysis, substrate leachate analysis, and shoot nutrient analysis were subjected to analysis of variance using the general linear model in SAS [Proc GLM (SAS version 9.1; SAS Institute, Cary, $\mathrm{NC})]$ to determine statistical differences for main effects (substrate or $\mathrm{CRF}$ ), interactions (substrate $\times \mathrm{CRF}$ ), and pairwise comparisons between treatments with Tukey's honest significant difference test $[P=0.05$ (SAS version 9.1)]. Because there were no differences in results between Expts. 1 and 2, we pooled the data. We also ran linear and quadratic regressions on shoot dry weight, root dry weight, and substrate EC with respect to changes in fertilizer application rate.

\section{Results and discussion}

The goal of these experiments was to determine if sand production techniques used to grow hydrilla could be used to grow southern naiad. We observed that average southern naiad shoot and root dry weights were greater in $100 \%$ sand than in $0 \%$ sand (Fig. 1). In production studies, hydrilla shoot dry weight was greater in the fertilized sand than in the muck-sand substrate (Sutton, 1985). In central and southern parts of Florida where soils are mostly sandy loam and low in nutrients, large concentrations of southern naiad have been reported (Novak et al., 2009). Southern naiad is widely distributed throughout the United States and has adapted to local environments and seasonal variations in the United States and Florida (Fernald, 1923; Main et al., 2006).

The second question answered with these experiments relates to the CRF rate associated with maximum southern naiad growth. Southern naiad shoot and root dry weight response to increasing CRF rate varied with the substrate (Fig. 1). Shoot dry weight in $100 \%$ sand increased as fertilizer rate increased from 0 to 2 $\mathrm{g} \cdot \mathrm{kg}^{-1}$ CRF and then decreased at higher fertilizer rates whereas shoot

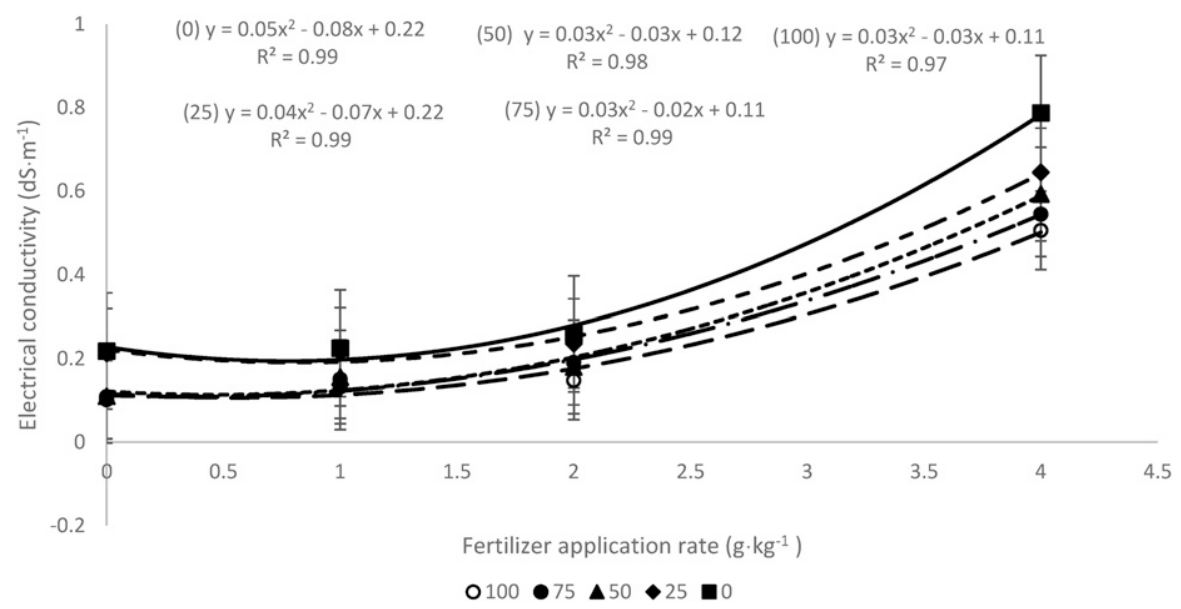

Fig. 2. Mean final substrate electrical conductivity for southern naiad plants fertilized with $0,1,2$, or $4 \mathrm{~g} \cdot \mathrm{kg}^{-1}$ controlled-release fertilizer and grown in 100:0, 75:25, 50:50, 25:75, or 0:100 sand:peat substrate (by volume). Data are from Expt. 2 conducted in June to July 2015 at the University of Florida, Fort Lauderdale Research and Education Center (Davie, FL). The numbers 100, 75, 50,25 , and 0 in the figure refer to the percent sand in the substrate. Bars represent $\mathrm{SE} ; 1 \mathrm{~g} \cdot \mathrm{kg}^{-1}=1000 \mathrm{ppm}, 1 \mathrm{dS} \cdot \mathrm{m}^{-1}=1 \mathrm{mmho} / \mathrm{cm}$. 
dry weight in the $75 \%, 50 \%$, and $25 \%$ sand increased from 0 to $1 \mathrm{~g} \cdot \mathrm{kg}^{-1} \mathrm{CRF}$ and then decreased. Shoot and root dry weight in the $0 \%$ sand decreased as fertilizer rate increased. Root dry weight of plants in $100 \%, 75 \%$, and $50 \%$ sand increased from 0 to $1 \mathrm{~g} \cdot \mathrm{kg}^{-1}$ $\mathrm{CRF}$ and then decreased whereas root dry weight in the $25 \%$ sand decreased as fertilizer rate increased. In a previous study, we observed shoot dry weight of southern naiad plants grown in $100 \%$ sand was greatest at 1-2 $\mathrm{g} \cdot \mathrm{kg}^{-1}$ CRF, whereas shoot dry weight of hydrilla in 100\% sand was greatest at $2-4 \mathrm{~g} \cdot \mathrm{kg}^{-1} \mathrm{CRF}$ (Hasandras et al., 2015). In another study, maximum hydrilla shoot growth in sand occurred at the two highest CRF rates of 1.6-2.3 g. $\mathrm{kg}^{-1}$ CRF (Osmocote $18 \mathrm{~N}-2.6 \mathrm{P}-10 \mathrm{~K}, 8-9$ months release) (Sutton, 1985).

The next obvious question is why we observed different growth responses of southern naiad to increasing CRF rates in the five substrates examined. For all substrates examined, as the CRF rate increased from 0 to $4 \mathrm{~g} \cdot \mathrm{kg}^{-1} \mathrm{CRF}$, substrate EC increased (Fig. 2). Substrate EC levels averaged for CRF rates were higher in the $0 \%$ sand than in the other substrates. Sphagnum moss has a higher cation exchange capacity and greater nutrient reserves than sand (Nelson, 2003 ). It is possible that the $0 \%$ sand ( $100 \%$ sphagnum peat) retained more nutrients released from the CRF leading to higher soluble salt levels in the substrate and reduced southern naiad growth. However, in our study substrate $\mathrm{pH}$ was not different because of the percentage of sand or fertilizer rate and ranged from 5.9 to 6.3 .

Reduced southern naiad growth and reduced $\mathrm{P}$ shoot nutrient concentrations were observed in all of the plants fertilized with $4 \mathrm{~g} \cdot \mathrm{kg}^{-1} \mathrm{CRF}$ (Table 1). Shoot P levels were greater in pots fertilized with 1 and $2 \mathrm{~g} \cdot \mathrm{kg}^{-1}$ CRF than 0 or $4 \mathrm{~g} \cdot \mathrm{kg}^{-1} \mathrm{CRF}$. High levels of $\mathrm{P}$ in hydrilla shoots were associated with high concentrations of CRF with hydrilla shoot P levels $0.06 \%$ for plants fertilized with 2.3 $\mathrm{g} \cdot \mathrm{kg}^{-1} \mathrm{CRF}$ vs. $0.04 \%$ for those with no fertilizer (Sutton, 1985). However, $\mathrm{N}$ and $\mathrm{K}$ in hydrilla shoots were the same in sand without fertilizer compared with plants grown with fertilizer (Sutton, 1985). In our study, southern naiad shoot $\mathrm{NO}_{3}-\mathrm{N}$ and $\mathrm{K}$ were similar at all fertilization rates. Another study determined that the tissue $\mathrm{N}, \mathrm{P}$, and $\mathrm{K}$ contents in hydrilla were related to the $\mathrm{N}, \mathrm{P}$, and $\mathrm{K}$ contents in the soil. Phosphorus and $\mathrm{N}$ were more dependent on the fertility of the hydrosoil than the nutrients in the water around the plant (Steward, 1984).

A concern with using CRF in submerged systems is the release rate of N, P, Kand other nutrients into the surrounding water. In our experiment, the water analysis showed no differences in $\mathrm{pH}, \mathrm{EC}, \mathrm{NO}_{3}-\mathrm{N}, \mathrm{PO}_{4}-\mathrm{P}$, or $\mathrm{K}$ due to CRF rates (Table 2). Because we used pots without holes and layered the CRF below the surface of substrate, we did not expect to observe nutrient release into the surrounding water. In the hydrilla study, there appeared to be little movement of nutrients from the zone where the CRF had been placed, indicating that the use of sand amended with various fertilizers layered into the sand simulated zones of nutrients that may occur in sediments under natural conditions (Sutton, 1985).

In conclusion, the use of $100 \%$ sand with $2 \mathrm{~g} \cdot \mathrm{kg}^{-1} \mathrm{CRF}$ layered $\mathrm{I}$ inch under the surface of the substrate produced the best southern naiad growth in a submerged environment. It would be interesting to observe transplant success of southern naiad produced using this protocol into the natural aquatic ecosystem to see if stronger transplants would

Table 1. Shoot concentrations of extractable nitrate-nitrogen $\left(\mathrm{NO}_{3}-\mathrm{N}\right)$, total phosphorus ( $\mathrm{P})$, and total potassium $(\mathrm{K})$ in southern naiad plants harvested from the Expt. 2 conducted from June to July 2015 at the University of Florida, Fort Lauderdale Research and Education Center (Davie, FL). Plants were fertilized with $0,1,2$, or $4 \mathrm{~g} \cdot \mathrm{kg}^{-1}$ controlled-release fertilizer (CRF) and grown in 100:0, 75:25, 50:50, 25:75, or 0:100 sand:peat substrate (by volume).

\begin{tabular}{lccc}
\hline $\mathrm{CRF}\left(\mathrm{g} \cdot \mathrm{kg}^{-1}\right)^{\mathrm{z}}$ & $\mathrm{N0}_{3}-\mathrm{N}\left(\mathrm{mg} \cdot \mathrm{g}^{-1}\right)^{\mathrm{z}}$ & $\mathbf{P}(\%)^{\mathrm{z}}$ & $\mathrm{K}(\%)$ \\
\hline 0 & $17.39 \mathrm{a}^{\mathrm{y}}$ & $0.034 \mathrm{~b}$ & $1.26 \mathrm{a}$ \\
1 & $17.49 \mathrm{a}$ & $0.054 \mathrm{a}$ & $1.41 \mathrm{a}$ \\
2 & $17.31 \mathrm{a}$ & $0.059 \mathrm{a}$ & $1.51 \mathrm{a}$ \\
4 & $17.49 \mathrm{a}$ & $0.031 \mathrm{~b}$ & $1.38 \mathrm{a}$
\end{tabular}

\begin{tabular}{llrl} 
Source of variance & \multicolumn{3}{c}{$P>F$} \\
Substrate & 0.5241 & 0.6324 & 0.5659 \\
CRF & 0.5417 & 0.0246 & 0.1117 \\
Substrate $\times$ CRF & 0.6784 & 0.4965 & 0.6852 \\
\hline
\end{tabular}

${ }^{\mathrm{z}} 1 \mathrm{~g} \cdot \mathrm{kg}^{-1}=1000 \mathrm{ppm}, 1 \mathrm{mg} \cdot \mathrm{g}^{-1}=1000 \mathrm{ppm}, \mathrm{l} \%=1 \mathrm{~g} \cdot \mathrm{L}^{-1}$.

${ }^{y}$ Means within a column followed by different letters are significantly different at $\alpha=0.05$ according to Tukey's honest significant difference test.

Table 2. Final water $\mathrm{pH}$, electrical conductivity (EC), nitrate-nitrogen $\left(\mathrm{NO}_{3}-\mathrm{N}\right)$, phosphate-phosphorus $\left(\mathrm{PO}_{3}-\mathrm{P}\right)$ and potassium $(\mathrm{K})$ of southern naiad plants from the Expt. 2 conducted in June 2015 at the University of Florida, Fort Lauderdale Research and Education Center (Davie, FL). Plants were fertilized with $0,1,2$, or $4 \mathrm{~g} \cdot \mathrm{kg}^{-1}$ controlled-release fertilizer (CRF) and grown in 100:0, $75: 25,50: 50,25: 75$, or 0:100 sand:peat substrate (by volume). Plants were grouped by CRF rate into 18-gal storage tubs with one container for each substrate. Values are means from water collected from three storage tubs per CRF rate.

\begin{tabular}{lccccc}
\hline $\mathrm{CRF}\left(\mathrm{g} \cdot \mathrm{kg}^{-1}\right)^{\mathrm{z}}$ & $\mathrm{pH}$ & $\mathrm{EC}\left(\mathrm{dS} \cdot \mathrm{m}^{-1}\right)^{\mathrm{z}}$ & $\begin{array}{c}\mathrm{NO}_{3}-\mathrm{N} \\
\left(\mathbf{m g} \cdot \mathbf{g}^{-1}\right)^{\mathrm{z}}\end{array}$ & $\begin{array}{c}\mathrm{PO}_{3}-\mathrm{P} \\
\left(\mathbf{m g} \cdot \mathbf{g}^{-1}\right)\end{array}$ & $\mathbf{K}\left(\mathbf{m g} \cdot \mathbf{g}^{-1}\right)$ \\
\hline 0 & $8.6 \mathrm{a}^{\mathrm{y}}$ & $0.398 \mathrm{a}$ & $0.353 \mathrm{a}$ & $0.257 \mathrm{a}$ & $0.90 \mathrm{a}$ \\
1 & $8.8 \mathrm{a}$ & $0.357 \mathrm{a}$ & $0.316 \mathrm{a}$ & $0.293 \mathrm{a}$ & $1.11 \mathrm{a}$ \\
2 & $8.6 \mathrm{a}$ & $0.354 \mathrm{a}$ & $0.394 \mathrm{a}$ & $0.294 \mathrm{a}$ & $0.84 \mathrm{a}$ \\
4 & $8.9 \mathrm{a}$ & $0.359 \mathrm{a}$ & $0.354 \mathrm{a}$ & $0.296 \mathrm{a}$ & $0.85 \mathrm{a}$ \\
& & & & & \\
Source of variance & & & $P>F$ & & \\
$\quad$ Replication & 0.8849 & 0.6395 & 0.9491 & 0.6815 & 0.7347 \\
$\quad$ CRF & 0.3938 & 0.0811 & 0.9683 & 0.0642 & 0.9491 \\
\hline
\end{tabular}

${ }^{\mathrm{z}} 1 \mathrm{~g} \cdot \mathrm{kg}^{-1}=1000 \mathrm{ppm}, \mathrm{ldS} \cdot \mathrm{m}^{-1}=1 \mathrm{mmho} / \mathrm{cm}, \mathrm{l} \mathrm{mg} \cdot \mathrm{g}^{-1}=1000 \mathrm{ppm}$.

${ }^{\mathrm{y}}$ Means within a column followed by different letters are significantly different at $\alpha=0.05$ according to Tukey's honest significant difference test. 
successfully fill in areas previously occupied by removed invasive aquatic plant species.

\section{Literature cited}

Dibble, E.D., K.J. Killgore, and S.L. Harrel. 1996. Assessment of fish-plant interactions. Amer. Fish. Soc. Symp. 16:357-372.

Fernald, M.L. 1923. Notes on the distribution of najas in northeastern America. Rhodora 25:105-109.

Godfrey, R.K. and J.W. Wooten. 1981. Aquatic and wetland plants of southeastern United States: Dicotyledons. Vol. 2. Univ. Georgia Press, Athens, GA.

Hasandras, H., K. Moore, L.A. Gettys, and W. Vendrame. 2015. Growth of southern naiad (Najas guadalupenisis) and hydrilla (Hydrilla verticillata) using contolled-release fertilizer. Proc. Florida State Hort. Soc. 128:268-270.

Lang, H.J. 1996. Growing media testing and interpretation, p. 123-139. In: D.W. Reed (ed.). Water, media, and nutrition for greenhouse crops. Ball Publ., Batavia, IL.

Madsen, J.D., R.M. Stewart, K.D. Getsinger, R.L. Johnson, and R.M. Wersal. 2008.
Aquatic plant communities in Waneta Lake and Lamoka Lake, New York. Northeast. Nat. 15:97-110.

Main, M.B., G.M. Allen, and K.A. Langeland. 2006. Creating wildlife habitat with native Florida freshwater wetland plants. Univ. Florida Circ. 912.

Miller, R.O. 1998. Extractable chloride, nitrate, orthophosphate, potassium, and sulfate-sulfur in plant tissue: $2 \%$ acetic acid extraction, p. 115-118. In: Y.P. Kalra (ed.). Handbook of reference methods for plant analysis. CRC Press, Boca Raton, FL.

Mony, C., T.J. Koschnick, W.T. Haller, and S. Muller. 2007. Competition between two invasive Hydrocharitaceae (Hydrilla verticillata (Lf)(Royle) and Egeria densa (Planch) as influenced by sediment fertility and season. Aquat. Bot. 86:236-242.

Nelson, P.V. 2003. Root substrate, p. 197-236. In: Greenhouse operation and management. Prentice Hall, Englewood Cliffs, NJ.

Novak, J.M., W.J. Busscher, D.L. Laird, M. Ahmedna, D.W. Watts, and M.A.S. Niandu. 2009. Impact of biochar amendment on fertility of a southeastern coastal plain soil. Soil Sci. 174:105-112.
Office of Technology Assessment. 1993. Harmful non-indigenous species in the United States. Office Technol. Assessment, Washington, DC.

Smart, R.M., R. Doyle, J.D. Madsen, and G.O. Dick. 1996. Establishing native submersed aquatic plant communities in southern reservoirs. Army Engineer Waterways Expt. Sta. Vicksburg, MS Environ. Lab. No. WES/TR/A-96-2. I June 2015. <http://el.erdc.usace.army.mil/ elpubs/pdf/tra96-2.pdf>.

Steward, K.K. 1984. Growth of hydrilla (Hydrilla verticillata) in hydrosoils of different composition. Weed Sci. 32:371-375.

Sutton, D.L. 1985. Culture of hydrilla (Hydrilla verticillata) in sand root media amended with three fertilizers. Weed Sci. $32: 371-375$.

Sutton, D.L. 1990. Comparison of two methods of evaluating growth of hydrilla in sediments collected from Lake Okeechobee. J. Aquat. Plant Mgt. 28:80-83.

University of Florida. 2015. Florida waters: Ours to protect. I June 2015. <http:// plants.ifas.ufl.edu/wp-content/uploads / files/caip/pdfs/Florida_Waters_Ours_to_ Protect.pdf $>$. 